Egypt. Acad. J. biolog. Sci., 1(1): 33-43 (2009)

Email: egyptianacademic@yahoo.com

Received: 5/9/2009
C. Physiology \& Molecular Biology

ISSN: 2090-0767

www.eajbs.eg.net

\title{
Effect of a single dose of a bradykinin potentiating factor isolated from scorpion venom (Buthus occitanus) on total protein and albumin in serum of irradiated growing male Guinea pigs.
}

\author{
Muhammad M. A. Salman \\ Zoology Department, Faculty of Science, South Valley Univesity, Qena, Egypt.
}

\begin{abstract}
Whole body gamma irradiation of growing male Guinea pigs at the dose of 150 rads/animal reduced the levels of total protein and albumin. Growing Guinea pigs males $(250 \pm 30$ gm. b. w.) were divided into two main groups; non-irradiated and irradiated groups and every main group were divided into four sub-groups. Irradiated growing Guinea pigs males groups were exposed to 150 Rads/animal by cesium-137 irradiation unit with a dose route of $1.06483 \mathrm{rad}$ per second in a uniform manner and divided into four sub-groups. In irradiated groups; the first sub-groups were interaperitoneally (i.p) injected with $100 \mu \mathrm{L}$ saline solution. The second sub-groups were i.p. injection of bone marrow cells from their twins $\left(2.5 \times 10^{6}\right.$ cells/animall $)$. The third sub-groups injected i. p with BPF $(1 \mu \mathrm{gm} / \mathrm{gm}$. b. w.) which was dissolved in saline solution.

The fourth sub-group injected with i.p solution of BPF $(1 \mu \mathrm{g} / \mathrm{gm}$. b. w.) together with bone marrow cells from their twins $\left(2.5 \times 10^{6}\right.$ cells/animal $)$. The nonirradiated sub-groups were injected with the same manner of irradiated sub-groups. The level of total protein and albumin in serum were measured at periods of $1,3,7$, 14 and 21 days. Irradiated animals i.p. injection of BPF (single dose); appears slight to improve the changes which occurred in both total protein and albumin compared to irradiated sub-group. However, irradiated Guinea pigs injected with single dose of BPF together with bone marrow cells were more improvement of these parameters than sub-groups injected with only single dose of BPF. The improvement of these parameters may be attributed to stimulate growth factors and/or growth hormones to increase protein synthesis as an effect on the liver that necessitates future investigations.
\end{abstract}

Key words: Irradiation, Bradykinin potentiting factor, total protein, Albumin and Guinea pigs.

\section{INTRODUCTION}

Ionizing radiation interacts with biological system through free radicals generated by water radiolysis. It is generally agreed that this indirect action plays an important role in the induction of oxidative stress leading to cellular damage and organ dysfunction (Berroud et al., 1996 and Othman, 1998). It worthy to mention that apoptosis, as a physiological contrast of mitosis, arises during early post-irradiation period as a response to blockade of mitotic activity and causes it's abortive effect on bone marrow cellularity (Vlasov and Kvacheva, 1998; El-Missiry et al., 1998 and 2007 and El-Missiry, 1999).

Serum proteins are synthesized and secreted by several cell types depending on the nature of the individual serum protein. The major functions of these proteins is maintenance of osmotic pressure intravascularly and hence maintenance of blood pressure and fluids in the circulation. They also carry out transport and storage function for several minerals, growth factors and hormones. Another strategic 
function of serum proteins is a defensive function mediated by gamma globulins produced by mature B-lymphocyte (Guyton and Hall, 2000). It worthy to mentioning that, whole body gamma irradiation caused changes in the serum globulins in irradiated Guinea pigs (Salman 2002). Moreover, braykinin stimulates the mitotic activity of bone marrow and thymus cells of irradiated mice (Sukhanova et al., 1977 and Sukhanova, 1986). Furthermore, Nassar and Soliman (1989) isolated BPF1, BPF2 and BPF3 from the Egyptian scorpions, Buthus occitanus and Leiurus quinquestriatus as well as the Cobra; Naja haje haje respectively. In vitro study of physiological activities of these fractions was found to be similar to those of BPFp and BPFc isolated from venom of Bothrops jararaca BPF of Buthus occitanus venom showed growth factor-like activity. This activity was decreased by addition of bradykinin inhibitors on cellular cultures of Baby Hamster kidney (BHK21) cell line. Also in female mice, this fraction enhanced development of the ovarian follicles and the cellular growth of the uterus as well as the level of female sex hormone estradiol (Nassar et al., 1989, 1990, 1991 and 1992). It worth to mentioning that, bradykinin potntiating factors have been isolated from snakes, vipers, scorpions and jelly fish venoms (Abu-Amra, 1994, 2000, 2001a and b, Abd-El-Rahim, 1990 and 1995, AbuAmra and Abd-El-Rahim, 1992 a and b; Abd-El-Rahim and Abu-Amra, 1992; Salman, 1995; Abd-El-Rahim et al., 1996 and Salman, 2002 and 2008). Additionally, Salman (1995) showed that scorpion venom fraction (BPF) accelerates burn wound repair. The mechanism of action was attributable to direct growth factor-like effects and/or indirect stimulation of endogenous bradykinin, which in turn stimulated endogenous prostaglandin biosynthesis. In particular, the elevated level of prostaglandin E2 fraction, a cytoprotective regulatory substance, might be the responsible effectors for such an accelerated burn wound healing. Remarkably, the extract induced complete re-epithelialization of the surface with abundant connective tissue in the dermis (Salman, 1995). Moreover, (Salman, 2002) showed that injection of BPF in sub-lethally-irradiated and non-irradiated Guinea pig accelerated the generation of thymus and spleen cellularity and completely recovered; the normal platelets, WBCs, RBCs and blood picture without noticeable toxic effects in nonirradiated control animals. Based on the aforementioned proliferation-inducing and cytoprotectant abilities of BPF of Buthus occitanus venom, this work has been designed to assess the ameliorating effect of interaperitoneally (i. p.) injected BPF only and i.p. injection of bone marrow (BM) cells from their twins $\left(2.5 \times 10^{6}\right.$ cells/animal) together with BPF on irradiated male Guinea pigs.

\section{Materials and Methods:}

Two hundreds male growing guinea pigs of approximate age and weight (4 month and about $(250 \pm 30 \mathrm{gm} \mathrm{b}$. w.) were selected from the Animal House Facility of the Egyptian Organization for Biological Products and Vaccines (VACSERA), Helwan, Cairo, Egypt. The animals were housed in the Animal House of the Faculty of Science, South Valley University, Qena, Egypt, for two weeks under the natural day and night periods and supplied with a balanced diet and water ad libitum. Bradykinin potentiating factor was previously isolated from the venom of the scorpion Buthus occitanus (Salman, 1995 and 2002) according to the chemical method of Ferreira (1965). The LD50 of this factor was determined according to the method of Meier and Theakston (1986). The animals were allocated into two main groups; nonirradiated and irradiated groups (100 individual each). The first main group (nonirradiated group) was subdivided into four sub-groups (25 animals each). The first sub-group was injected with saline solution $(100 \mu \mathrm{L})$ and considered as control. The second sub-group was i. p. injection $1 \mu \mathrm{gm} / \mathrm{gm}$ b. w. of bradykinin potentiating factor 
isolated from the venom of scorpion, Buthus occitanus and was solvent in saline solution. The third sub-groups were i.p. injection of bone marrow cells from their twins $\left(2.5 \times 10^{6}\right.$ cells/animal). The fourth sub-group injected i. p of BPF $(1 \mu \mathrm{g} / \mathrm{gm}$. b. w.) was dissolved in saline solution together with i. p. injection of bone marrow cells from their twins $(2.5 \times 106$ cells/animal). Irradiated sub-groups were also divided into four sub-groups. Irradiated growing Guinea pigs males sub-groups were exposed to 150 Rads/animal by by cesium-137 irradiation unit with a dose route of 1.06483 rads per second in a uniform manner and divided into four sub-groups. The irradiated subgroups were injected with the same manner of non-irradiated sub-groups Biochemical analysis

Sample collection: Five animals were sacrificed from each sub-group of nonirradiated and irradiated at 1,3 7, 14 and 21days post-irradiated and treatment with bradykinin potentiating factor. Peripheral blood was left in clean tubes at room temperature to clot. After an hour, serum was separated by centrifugation for 30 minutes at $3000 \mathrm{rpm}$. (Dacie and Lewis, 1975). The sera were collected in aliquots in labeled- Epindorff's tubes and stored at $-20{ }^{\circ} \mathrm{C}$ until used for determination of total protein and albumin.

Determination of total serum protein level: Determination of total serum protein level was estimated according to Peters (1968) method.

Reagents: Potassium-sodium-tartrate $(15 \mathrm{mmol})$, sodiumodide (100 mmol), potassium iodide $(15 \mathrm{mmol})$, copper sulphate $(5 \mathrm{mmol})$ produced by LABKIT-Josep Tarradellas, cat. no. 8008029 Barceilona, Spain code no. 30350.

Determination of serum albumin level: Serum albumin was determined according to the method described by Doumas et al.(1971 and 1972)

Reagent: Bromcresol green pH 4.2, 50 mmol produced by LABKIT-plató, 6 cat. no. E-08021 Barcelona, Aspin, cod. No.30120. Using spectrophotometer (Spectronic 601 Item 335104 MB, Serl. 3614203016, Milton Ro. Company, 820 Linden Avenue, Rochester, NY 14625m U.S.A)

Statistical analysis

Data are presented as standard error (S.E.) of the means and were statistically analyzed using SPSS version 8.0 of Software. Differences between moments were analyzed by Kruskal-Wallis Test and parameters of each test group were compared with control group by Mann-Whitney Test. Results were considered significant when $\mathrm{p}$ value was lower than 0.05 .

\section{RESULTS}

\section{1)Serum total protein content:}

Effect of BM cell, BPF or both in non-irradiated animals. The results presented in table (1) show that administration of B. M. cells $\left(2.5 \times 10^{6}\right.$ cells/animal $)$ to the normal non irradiated guinea pigs did not induce significant difference change of their serum total protein content from their corresponding control values during the 21 days test period. On the other hand, i.p. injection of a single dose BPF isolated from the scorpion, B. occitanus venom to the normal animals induced a significant increase of their mean serum total protein content. This increase was a pronouncing and reached $93.13 \%(\mathrm{P}<0.01)$ after one day $34.7 \%(\mathrm{P}<0.5)$ after three days and $8.92 \%$ $(\mathrm{P}<0.05)$ after 7 days of treatment respectively. However, after 14 and 21 days of treatment there was no significant change of the mean serum total protein level from that of the corresponding control value (Table 1). Furthermore, the combination treatment with both of BM cells and a single venom fraction BPF dose enhanced the 
increase of mean serum total protein level determined after each of $24 \mathrm{~h}, 3$ days and 7 days test period (Table 1). The increases recorded after 14 and 21 days were insignificant from the corresponding control value (Table 1).

\section{2) Effect of whole body irradiation on serum total protein:}

On the other hand, whole body irradiation of guinea pigs (1.5 Gy) induced a remarkable decrease in serum total protein level $(29.06 \% ; \mathrm{P}<0.05)$ after $24 \mathrm{~h}$ of irradiation. Such decrease was evident after 3 days $(35.81 \%$; $\mathrm{P}<0.05)$ and after 7 days $(65.05 \% ; \mathrm{P}<0.001)$ of radiation exposure (Table 1). After 14 and 21 days of irradiation the mean serum total protein level was still significantly lower $(63.62 \%$; $\mathrm{P}<0.001$ and $60.16 \% ; \mathrm{P}<0.01$ respectively) than the corresponding control level (Table 1 ).

Table (1): Effect of intraperitoneal injection of a single dose $(1 \mu \mathrm{g} / \mathrm{gm}$ body weight) of BPF from scorpion; Buthus occitanus (BPF), $2.5 \times 10^{6}$ BMCs or BMCs together with BPF on total serum protein level of non-irradiated and groups of growing male Guinea pigs at 1, 3, 7, 14 and 21 days post-treatment.

\begin{tabular}{|c|c|c|c|c|c|c|c|c|c|}
\hline \multirow{2}{*}{ Days } & \multirow{2}{*}{$\begin{array}{c}\text { Groups } \\
\text { Treatments }\end{array}$} & \multicolumn{4}{|c|}{ Non-irradiated groups } & \multicolumn{4}{|c|}{ Irradiated groups } \\
\hline & & Control & $\mathrm{BMCs}$ & $\mathrm{BPF}$ & $\begin{array}{c}\mathrm{BMCs}^{+} \\
\mathrm{BPF}\end{array}$ & I & $\mathrm{I}+\mathrm{BMCs}$ & $\mathrm{I}+\mathrm{BPF}$ & $\mathrm{I}+\mathrm{BMCs}+\mathrm{BPF}$ \\
\hline \multirow{3}{*}{$\begin{array}{l}\text { After } \\
\text { One } \\
\text { days }\end{array}$} & $\begin{array}{c}\text { Mean } \pm \text { S.E. } \\
\text { gm/dL }\end{array}$ & $\begin{array}{c}5.3104 \\
\pm \\
0.163\end{array}$ & $\begin{array}{c}5.4158 \\
\pm \\
0.386\end{array}$ & $\begin{array}{c}10.2558 \\
\pm \\
0.390\end{array}$ & $\begin{array}{c}11.5682 \\
\pm \\
0.373\end{array}$ & $\begin{array}{c}3.7672 \\
\pm \\
0.264\end{array}$ & $\begin{array}{c}4.1530 \\
\pm \\
0.293\end{array}$ & $\begin{array}{c}5.5022 \\
\pm \\
0.288\end{array}$ & $\begin{array}{c}7.01582 \pm \\
0.290\end{array}$ \\
\hline & $\%$ of change & & +1.98 & +93.13 & +117.84 & -29.06 & -21.79 & +3.61 & +32.114 \\
\hline & Significance & & NS & $\mathrm{P}<0.01$ & $\mathrm{P}<0.001$ & $\mathrm{P}<0.05$ & $\mathrm{P}<0.05$ & NS & $\mathrm{P}<0.05$ \\
\hline \multirow[t]{3}{*}{$\begin{array}{l}\text { After } \\
3 \\
\text { days }\end{array}$} & $\begin{array}{c}\text { Mean } \pm \text { S.E. } \\
\text { gm/dL }\end{array}$ & $\begin{array}{c}5.2042 \\
\quad \pm \\
0.188\end{array}$ & $\begin{array}{c}5.4314 \\
\pm \\
0.168\end{array}$ & $\begin{array}{c}7.0100 \\
\pm \\
0.165\end{array}$ & $\begin{array}{c}8.6342 \\
\pm \\
0.197\end{array}$ & $\begin{array}{c}3.3406 \\
\pm \\
0.199\end{array}$ & $\begin{array}{c}4.3808 \\
\pm \\
0.187\end{array}$ & $\begin{array}{c}5.5048 \\
\pm \\
0.199\end{array}$ & $\begin{array}{c}5.886 \\
\pm \\
0.180\end{array}$ \\
\hline & $\%$ of change & & +4.37 & +34.70 & +65.91 & -35.81 & -15.82 & +5.776 & +13.10 \\
\hline & significance & & NS & $\mathrm{P}<0.05$ & $\mathrm{P}<0.01$ & $\mathrm{P}<0.05$ & $\mathrm{P}<0.05$ & NS & $\mathrm{P}<0.05$ \\
\hline \multirow[t]{3}{*}{$\begin{array}{l}\text { After } \\
7 \\
\text { days }\end{array}$} & $\begin{array}{c}\text { Mean } \pm \text { S.E. } \\
\text { gm/dL }\end{array}$ & $\begin{array}{c}5.155 \\
\pm \\
0.1856\end{array}$ & $\begin{array}{c}5.2768 \\
\pm \\
0.19169\end{array}$ & $\begin{array}{c}5.615 \\
\pm \\
0.108\end{array}$ & $\begin{array}{c}6.0062 \\
\pm \\
0.178\end{array}$ & $\begin{array}{c}1.8016 \\
\pm \\
0.193\end{array}$ & $\begin{array}{c}2.5802 \\
\pm \\
0.187\end{array}$ & $\begin{array}{c}3.8032 \\
\pm \\
0.180\end{array}$ & $\begin{array}{c}4.3084 \\
\pm \\
0.180\end{array}$ \\
\hline & $\%$ of change & & +2.36 & +8.92 & +16.51 & -65.05 & -49.95 & -26.22 & -16.42 \\
\hline & significance & & NS & $\mathrm{P}<0.5$ & $\mathrm{P}<0.05$ & $\mathrm{P}<0.001$ & $\mathrm{P}<0.01$ & $\mathrm{P}<0.05$ & $\mathrm{P}<0.05$ \\
\hline \multirow[t]{3}{*}{$\begin{array}{l}\text { After } \\
14 \\
\text { days }\end{array}$} & $\begin{array}{c}\text { Mean } \pm \text { S.E. } \\
\text { gm/dL }\end{array}$ & $\begin{array}{c}5.230 \\
\pm \\
0.144 \\
\end{array}$ & $\begin{array}{c}5.044 \\
\pm \\
0.181 \\
\end{array}$ & $\begin{array}{c}5.250 \\
\pm \\
0.121 \\
\end{array}$ & $\begin{array}{c}5.3866 \\
\pm \\
0.126 \\
\end{array}$ & $\begin{array}{c}1.9027 \\
\pm \\
0.185 \\
\end{array}$ & $\begin{array}{c}2.630 \\
\pm \\
0.150 \\
\end{array}$ & $\begin{array}{c}3.1230 \\
\pm \\
0.140 \\
\end{array}$ & $\begin{array}{c}3.500 \\
\pm \\
0.187 \\
\end{array}$ \\
\hline & $\%$ of change & & -3.56 & +0.38 & +2.99 & -63.62 & -49.71 & -40.29 & -33.08 \\
\hline & significance & & NS & NS & NS & $\mathrm{P}<0.001$ & $\mathrm{P}<0.01$ & $\mathrm{P}<0.01$ & $\mathrm{P}<0.05$ \\
\hline \multirow[t]{3}{*}{$\begin{array}{l}\text { After } \\
21 \\
\text { days }\end{array}$} & $\begin{array}{c}\text { Mean } \pm \text { S.E. } \\
\mathrm{gm} / \mathrm{dL}\end{array}$ & $\begin{array}{c}5.2446 \\
\pm \\
0.1730\end{array}$ & $\begin{array}{c}5.280 \\
\pm \\
0.110\end{array}$ & $\begin{array}{c}5.448 \\
\pm \\
0.194 \\
\end{array}$ & $\begin{array}{c}5.368 \\
\pm \\
0.193\end{array}$ & $\begin{array}{c}2.089 \\
\pm \\
0.138 \\
\end{array}$ & $\begin{array}{c}2.957 \\
\pm \\
0.171 \\
\end{array}$ & $\begin{array}{c}3.408 \\
\pm \\
0.150\end{array}$ & $\begin{array}{c}4.982 \\
\pm \\
0.180\end{array}$ \\
\hline & $\%$ of change & & +0.67 & +3.88 & $\begin{array}{l}+2.353 \\
\end{array}$ & -60.17 & -43.62 & -35.02 & -5.01 \\
\hline & significance & & NS & NS & NS & $\mathrm{P}<0.01$ & $\mathrm{P}<0.01$ & $\mathrm{P}<0.05$ & NS \\
\hline $\begin{array}{l}\mathrm{N} \\
\mathrm{P} \\
\mathrm{NS} \\
\mathrm{BPI} \\
\mathrm{BM} \\
\mathrm{I}\end{array}$ & $\begin{array}{l}=5 \text { animal } \\
=\text { Significa } \\
=\text { Insignific } \\
=\text { Bradykin } \\
=\text { Bone mar } \\
=\text { Irradiated }\end{array}$ & $\begin{array}{l}\text { yere use } \\
\text { y differe } \\
\text { tly diffe } \\
\text { potentia } \\
\text { N. }\end{array}$ & $\begin{array}{l}\text { each ge } \\
\text { from the } \\
t \text { from } t\end{array}$ & $\begin{array}{l}\text { p. } \\
\text { ntrol. } \\
\text { control. }\end{array}$ & & & & & \\
\hline
\end{tabular}

Effect of treatment with BM cells, BPF or both on irradiated animals: Treating the irradiated animals with BM cells $3 \mathrm{~h}$ after irradiation slightly ameliorated the total protein content to be $21.79 \%(\mathrm{P}<0.05)$ lower than that of the control level after $24 \mathrm{~h}$ of treatment. However, while this amelioration was complete after 3 days of radiation exposure it was also incomplete after 7, 14 and 21 days of treatment and total protein level was significantly lower than that of corresponding control value by $15.82 \%$ $(\mathrm{P}<0.05), 49.95 \%(\mathrm{P}<0.01)$ and $49.71 \%(\mathrm{P}<0.01)$ respectively as shown in (Table 1$)$. Treating the irradiated animals with a single dose of BPF showed also a recovery of the mean serum total protein content of guinea pigs and the level was $3.61 \%$ higher than that of the corresponding control value after one day of treatment. This effect was enhanced after three days and the increase of serum total protein level was $5.78 \%$ 
higher than that of the control value. After 7 days the total protein level was significantly lower from that of the mean control value, $(26.22 \% ; \mathrm{P}<0.05)$ as shown in table (1). This decrease of the serum total protein level of irradiated animals that were treated with a single dose of BPF was a significantly lower than that of the corresponding control after 14 days $(40.29 \% ; \mathrm{P}<0.01)$ and 21 days $(35.02 \% ; \mathrm{P}<0.05)$ respectively (Table 1). On the other hand, the combined BM cells and a single dose of $\mathrm{BPF}$ treatments of the irradiated guinea pigs resulted in remarkable increase of serum total protein level after one $(32.11 \% ; \mathrm{P}<0.05)$ and 3 days $(13.11 \% ; \mathrm{P}<0.05)$ of treatment in comparison with that the corresponding control animals as shown table (1). However, this amelioration was incomplete after 7 days of treatment and the mean serum total protein level was significantly lower than that of corresponding control value by $16.50 \%(\mathrm{P}<0.05)$ as shown in (Table 1$)$. These results indicate a significant decrease also of serum total protein level due to this combined treatment by $33.08 \%(\mathrm{P}<0.05)$ and $5.0 \%$ after 14 and 21 days of irradiation respectively (Table 1$)$.

\section{Serum albumin content:}

1) Effect of BM cell, BPF or both in non-irradiated animal in table (2) show that administration of BM cells $\left(2.5 \times 10^{6}\right.$ cells/animal $)$ to the normal non irradiated Guinea pigs did not induce significant difference change of their serum albumin content from their corresponding control values during the 21 days test period. On the other hand, i.p. injection of a single dose BPF isolated from the scorpion, B. occitanus venom to the normal animals induced a significant increase of their mean serum albumin content. This increase was a pronouncing and reached 36.20\% $(\mathrm{P}<0.01)$ after one day $9.20 \%(\mathrm{P}<0.5)$ after three days and $8.92 \%(\mathrm{P}<0.05)$ after 7 days of treatment respectively. However, after 14 and 21 days of treatment there was no significant change of the mean serum albumin level from that of the corresponding control value (Table 2).

Table (2): Effect of intraperitoneal injection of a single dose $(1 \mu \mathrm{g} / \mathrm{gm}$ body weight $)$ of BPF from scorpion; Buthus occitanus (BPF), $2.5 \times 10^{6} \mathrm{BMCs}$ or BMCs together with BPF on serum albumin level of non-irradiated and irradiated groups of growing male Guinea pigs at 1,3 and 7,14 and 21 days post-treatment.

\begin{tabular}{|c|c|c|c|c|c|c|c|c|c|}
\hline \multirow[t]{2}{*}{ Days } & \multirow{2}{*}{$\begin{array}{r}\text { Groups } \\
\text { Treatments } \\
\end{array}$} & \multicolumn{4}{|c|}{ Non-irradiated groups } & \multicolumn{4}{|c|}{ Irradiated groups } \\
\hline & & Control & BMCs & BPF & $\mathrm{BMCs}+\mathrm{BPF}$ & I & I+BMCs & $\mathrm{I}+\mathrm{BPF}$ & $\mathrm{I}+\mathrm{BMCs}+\mathrm{BPF}$ \\
\hline \multirow[t]{3}{*}{$\begin{array}{l}\text { After } \\
\text { One day }\end{array}$} & $\begin{array}{c}\text { Mean } \pm \text { S.E. } \\
\text { gm/dL }\end{array}$ & $\begin{array}{c}3.4088 \\
\pm \\
0.185\end{array}$ & $\begin{array}{c}3.3132 \\
\pm \\
0.159\end{array}$ & $\begin{array}{c}4.6428 \\
\pm \\
0.121\end{array}$ & $\begin{array}{c}4.9944 \\
\pm \\
0.263\end{array}$ & $\begin{array}{c}2.4198 \\
\pm \\
0.196\end{array}$ & $\begin{array}{c}2.7146 \\
\pm \\
0.139\end{array}$ & $\begin{array}{c}3.162 \\
\pm \\
0.176\end{array}$ & $\begin{array}{c}3.669 \\
\pm \\
0.195\end{array}$ \\
\hline & \%of change & & -2.80 & +36.20 & +46.51 & -29.01 & -20.36 & -7.240 & +7.63 \\
\hline & Significance & & NS & $\mathrm{P}<0.01$ & $\mathrm{P}<0.01$ & $\mathrm{P}<0.05$ & $\mathrm{P}<0.05$ & NS & NS \\
\hline \multirow[t]{3}{*}{$\begin{array}{l}\text { After } \\
3 \text { days }\end{array}$} & $\begin{array}{c}\text { Mean } \pm \text { S.E. } \\
\text { gm/dL }\end{array}$ & $\begin{array}{c}3.3626 \\
\pm \\
0.104\end{array}$ & $\begin{array}{c}3.4382 \\
\pm \\
0.165\end{array}$ & $\begin{array}{c}3.6720 \\
\pm \\
0.115\end{array}$ & $\begin{array}{c}3.7442 \\
\pm \\
0.196\end{array}$ & $\begin{array}{c}2.0076 \\
\pm \\
0.173\end{array}$ & $\begin{array}{c}2.6076 \\
\pm \\
0.151\end{array}$ & $\begin{array}{c}3.000 \\
\pm \\
0.197\end{array}$ & $\begin{array}{c}3.0864 \\
\pm \\
0.160\end{array}$ \\
\hline & \%of change & & +2.25 & +9.20 & +11.35 & -40.30 & -22.45 & -10.78 & -8.21 \\
\hline & significance & & NS & $\mathrm{P}<0.05$ & $\mathrm{P}<0.05$ & $\mathrm{P}<0.01$ & $\mathrm{P}<0.05$ & NS & NS \\
\hline \multirow[t]{3}{*}{$\begin{array}{c}\text { After } \\
7 \\
\text { days }\end{array}$} & $\begin{array}{c}\text { Mean } \pm \text { S.E } \\
\mathrm{gm} / \mathrm{dl}\end{array}$ & $\begin{array}{c}3.3626 \\
\pm \\
0.179\end{array}$ & $\begin{array}{c}3.392 \\
\pm \\
0.121\end{array}$ & $\begin{array}{c}3.572 \\
\pm \\
0.120\end{array}$ & $\begin{array}{c}3.858 \\
\pm \\
0.171\end{array}$ & $\begin{array}{c}1.2754 \\
\pm \\
0.119\end{array}$ & $\begin{array}{c}1.754 \\
\pm \\
0.176\end{array}$ & $\begin{array}{c}2.7164 \\
\pm \\
0.1293 \\
\end{array}$ & $\begin{array}{c}2.9618 \\
\pm \\
0.112 \\
\end{array}$ \\
\hline & $\%$ of change & & +0.87 & +6.23 & +14.73 & -62.07 & -47.84 & -19.22 & -11.92 \\
\hline & significance & & NS & NS & $\mathrm{P}<0.05$ & $\mathrm{P}<0.001$ & $\mathrm{P}<0.01$ & $\mathrm{P}<0.05$ & NS \\
\hline \multirow[t]{3}{*}{$\begin{array}{l}\text { After } \\
14 \text { days }\end{array}$} & $\begin{array}{c}\text { Mean } \pm \text { S.E. } \\
\mathrm{gm} / \mathrm{dL}\end{array}$ & $\begin{array}{c}3.4026 \\
\pm \\
0.176 \\
\end{array}$ & $\begin{array}{c}3.32 \\
\pm \\
0.101 \\
\end{array}$ & $\begin{array}{c}3.454 \\
\pm \\
0.179 \\
\end{array}$ & $\begin{array}{c}3.5366 \\
\pm \\
0.147 \\
\end{array}$ & $\begin{array}{c}1.000 \\
\pm \\
0.162 \\
\end{array}$ & $\begin{array}{c}1.500 \\
\pm \\
0.113 \\
\end{array}$ & $\begin{array}{c}1.700 \\
\pm \\
0.159 \\
\end{array}$ & $\begin{array}{c}2.000 \\
\pm \\
0.169 \\
\end{array}$ \\
\hline & $\%$ of change & & -2.43 & +1.51 & +3.94 & -70.61 & -55.92 & -50.04 & -41.22 \\
\hline & significance & & NS & NS & NS & $\mathrm{P}<0.001$ & $\mathrm{P}<0.01$ & $\mathrm{P}<0.01$ & $\mathrm{P}<0.01$ \\
\hline \multirow[t]{3}{*}{$\begin{array}{c}\text { After } \\
21 \text { days }\end{array}$} & $\begin{array}{c}\text { Mean } \pm \text { S.E. } \\
\text { gm } / \mathrm{dL}\end{array}$ & $\begin{array}{c}3.3882 \\
\pm \\
0.111\end{array}$ & $\begin{array}{c}3.578 \\
\pm \\
0.209\end{array}$ & $\begin{array}{c}3.558 \\
\pm \\
0.295\end{array}$ & $\begin{array}{c}3.446 \\
\pm \\
0.194\end{array}$ & $\begin{array}{c}1.423 \\
\pm \\
0.171\end{array}$ & $\begin{array}{c}2.100 \\
\pm \\
0.195\end{array}$ & $\begin{array}{c}2.220 \\
\pm \\
0.186\end{array}$ & $\begin{array}{c}3.000 \\
\pm \\
0.114\end{array}$ \\
\hline & $\%$ of change & & +5.60 & +5.01 & +1.71 & -58.00 & -38.02 & -34.48 & -11.46 \\
\hline & Significance & & NS & NS & NS & $\mathrm{P}<0.001$ & $\mathrm{P}<0.01$ & $\mathrm{P}<0.01$ & $\mathrm{P}<0.05$ \\
\hline \multicolumn{10}{|c|}{$\begin{array}{l}\mathrm{NS}=\text { Insignificantly different from the control. } \\
\mathrm{BPF}=\text { Bradykinin potentiating factor (isolated scorpion venom fraction). } \\
\mathrm{BM}=\text { Bone marrow. }\end{array}$} \\
\hline
\end{tabular}


I = Irradiated.

Furthermore, the combination treatment with both of BM cells and a single venom fraction BPF dose enhanced the increase of mean serum albumin level determined after each of $24 \mathrm{~h}, 3$ days and 7 days test period (Table 2). The increases recorded after 14 and 21 days were insignificant from the corresponding control value (Table 2).

\section{2) Effect of whole body irradiation on serum albumin:}

On the other hand, whole body irradiation of guinea pigs (1.5 Gy) induced a remarkable decrease in serum total protein level $(29.01 \% ; \mathrm{P}<0.05)$ after $24 \mathrm{~h}$ of irradiation. Such decrease was evident after 3 days $(35.81 \%$; $\mathrm{P}<0.05)$ and after 7 days $(40.31 \% ; \mathrm{P}<0.01)$ of radiation exposure (Table 1). After 14 and 21 days of irradiation the mean serum albumin level was still significantly lower $(70.61 ; \mathrm{P}<0.001$ and 58.00; $\mathrm{P}<0.01$ ) respectively than the corresponding control level (Table 2 ).

\section{3) Effect of treatment with BM cells, BPF or both on irradiated animals:}

Treating the irradiated animals with $\mathrm{BM}$ cells $3 \mathrm{~h}$ after irradiation slightly ameliorated the albumin content to be 20.36; $(\mathrm{P}<0.05)$ lower than that of the control 1 evel after $24 \mathrm{~h}$ of treatment. However, while this improvement was complete after 3 days of radiation exposure it was also incomplete after 7, 14 and 21 days of treatment and serum albumin level was significantly lower than that of corresponding control value by $47.83 \%(\mathrm{P}<0.05), 55.91 \%(\mathrm{P}<0.01)$ and $38.02 \%(\mathrm{P}<0.01)$, respectively as shown in (Table 2). Treating the irradiated animals with a single dose of BPF showed also a recovery of the mean serum albumin content of Guinea pigs and the level was $7.24 \%$ lower than that of the corresponding control value after one day of treatment. However, while this improvement was complete after 3 days of radiation exposure it was also incomplete after 7,14 and 21 days of treatment and serum albumin level was significantly lower than that of corresponding control value by $19.21 \%(\mathrm{P}<0.05)$, $50.04 \%(\mathrm{P}<0.01)$ and $34.48 \%(\mathrm{P}<0.01)$ respectively as shown in (Table 2$)$. On the other hand, the combined BM cells and a single dose of BPF treatments of the irradiated guinea pigs resulted in increase of serum albumin level after one day (7.63\%). However, this amelioration was incomplete after 3 and 7 days of treatment and the mean serum total protein level was significantly lower than that of corresponding control value by $8.21 \%$ and $11.92 \%$ respectively as shown in (Table 1). These results indicate a significant decrease also of serum albumin level due to this combined treatment by $41.22 \%(\mathrm{P}<0.05)$ and $11.45 \%(\mathrm{P}<0.05)$ after 14 and 21 days of irradiation respectively (Table 2 ).

\section{DISCUSSION}

Recovery from irradiation effects has strongly attracted the attention of radiobiologist. They tried different means of treatment against irradiation effects as chemical and biological substances (Khamis, 1986 and Dong et al., 2009). This paper deals with the trial of using one of the most important biological cells in the body (bone marrow cells, bradykinin potentiating factor and combination bone marrow cells and bradykinin potentiating factor) for treatment post-irradiation. The liver is a major producer for most of serum proteins and its total level in the blood is a main liver function test. Irradiation has a destructive effect on all body tissues including the liver. This is very important in the context of the present studies considering the fact that the liver is the major source for endogenous kininogens (El-Asmar et al., 1975; Kehrer et al., 1990 and Abu-Amra and Abd-El-Rahim, 2000). It was reported that BPF injection causes activation of glycogen synthetase enzyme that increases 
liver content of glycogen. This increase has a liver protective effect and potentiates the detoxification efficiency of the liver (Basu et al., 1992; Abu-Amra, 1994; Muriel, 1998 and Schmaier et al., 1998). Futhermore, the hepatic synthesis of a number of plasma protein increased by IL-1 that is bradykinin-dependent in its secretion (Oppenheim et al., 1982; Tiffany and Burch, 1989; Zündorf et al., 1996 and Özotürk, 2001). It was noted that the irradiation-induced reduction in serum total protein and albumin were improved by the different treatments applied in the present study. BPF effect was dose-frequency dependent improvement the concentration total protein and albumin but did not reach complete recovery. Combined BPF and BM cells treatment was more efficient in normalizing serum total protein and albumin. It is worthy to mention that, radiation-induced renal injury (radiation nephropathy) is characterized by proteinuria, hypertension, and progressive decline in renal function (Cohen, 2001; Cohen et al., 2002 and Cohen and Robbins, 2003). In the present study the significant decrease in the serum level of total protein and albumin after irradiation was in agreement with previous results (Marinova et al., 1991). It is established that liver is the main source of plasma albumin. The decreases in serum total protein and albumin is mainly due to the diminishing of its synthesis in hepatic cells, accompanied by losses of large amounts of albumin into the urine and gastrointestinal tract due to damage kidney and intestinal mucosa (West, 1985). Karalenka et al., (1993) found that gamma irradiation leads to cessation of the transport of albumin into rat plasma. They concluded that the speed and the characters of that radiation effect depend both on dose and duration after irradiation. Albumin catabolism (Simsa and Mráz, 1974 and Waldmann, 1977) may differ fundamentally from the catabolism of the other plasma protein, since albumin is duration withdrawal the only plasma protein that is not a glycoprotein (Sharon and Lis, 1981). On the other hand, there are interactions between vasoactive polypeptides such as bradykinin and classical hormonal transmitters. Example of such interactions is that active polypeptides stimulate the synthesis or release of prolactin and growth hormone (Vijayan et al., 1979; Enjalbert et al., 1980; Frawley and Neil, 1981 and Chihara et al., 1982). More recently, Dong et al. (2009) reported that, the effect of scorpion venom polypeptide accelerating the hematopoietic recovery was potentially through a mechanism of stimulating the release of cytokines. Consequently, it is could be suggested that the endogenous bradykinin potentiated by venom fractions enhanced the release of growth hormone, cytokine and other growth factors, resulting in the stimulation of increase total protein and albumin. In conclusion the improvement of these parameters may be attributed to the induction of hematopoietic growth factors and/or amelioration of the injury effect of radiation on the liver that necessitates future investigation.

\section{REFERENCES}

Abd-El-Rahim, S. A. (1995): Effect of extracted crude venom of the jelly- fish, Eutonina indicans on kidney function. J. Egypt. Ger. Soc. Zool., 18 (A): 131 - 147.

Abd-El-Rahim, S. A. and Abu-Amra, E. (1992): Effect of a bradykinin pot- entiating fraction from the venom of the Egyptian scorpion, Buthus occitanus on the testis of mature mice. Proc. Zool. Soc., A. R. Egypt, 23: (part I): 115 - 122.

Abd-El-Rahim, S. A.; El-Sawi, N. M. and Abul-Dahab, H. M. (1996): Effect of extracted crude venom of the jellyfish, Eutonina indicans on liver function in male mice. J. Assiut. Vet. Med., 54 (68): 56 - 67. 
Abdel Rahman, N. and Roushdy, M. M. (1999): Alterations in histological pattern and DNA content of small intestine of albino mice exposed to fractionated doses of whole body gamma irradiation. J. Egypt. Ger. Soc. Zool., 28 (C): 1- 11.

Abu-Amra, E. (1994): Influence of venom extracted factors separated from snakes on serum insulin, serum glucose, liver glycogen and skeletal muscle pyruvate levels of rats. J. Egypt. Ger. Soc. Zool., 15 (A): 205 - 214.

Abu-Amra, E. (2000): Physiological studies on diabetic male albino mice treated with a bradykinin potentiating factors (BPF) separated from jellyfish and cobra snake venoms. 1- Effect of $\mathrm{BPF}_{7}$ and $\mathrm{BPF}_{3}$ on diabetic. J. Egypt. Ger. Soc. Zool., 33 (A): 211- 233.

Abu-Amra, E. (2001a): Physiological studies on diabetic male albino mice treated with a bradykinin potentiating factors of $\mathrm{BPF}_{7}$ and $\mathrm{BPF}_{9}$ on some phsiological parameters. Egypt. J. Zool., 36: 207 - 224.

Abu-Amra, E. (2001b): Physiological and structural studies on diabetic male mice treated with a bradykinin potentiating factor (BPF) separated from jellyfish venom. 4- Effect of $\mathrm{BPF}_{7}$ on fertility. Egypt. J. Zool., 36: 529 - 548.

Abu-Amra, E. and Abd-El-Rahim, S. A. (1992a): Activation of some enzymes activities of the plasma and liver of white rat by a venom fraction isolated from scorpion and snake. Proc. Zool. Soc. A. R. E., 32 (1): 123 - 128.

Abu-Amra, E. and Abd-El-Rahim, S. A. (1992b): Effect of factors isolated from venoms of Egyptian snakes in plasma cholesterol, creatine kinase and alkaline phosphatase. J.Egypt. Ger. Soc. Zool., 9: 75 - 89.

Abu-Amra, E. and Abd-El-Rahim, S. A. (2000): Stimulation of some enzymes and cellular proliferation by factors separated from scorpion and jellyfish. J. Egypt. Ger. Soc. Zool., 31: 273 - 287.

Basu, S. K.; Srinivasan, M. N.; Chuttani, K. and George, S. (1992): Protection to glycolysis by a combination of 5-hydroxy-L-tryptophan and 2-aminoethyl isothiuronium bromide hydrobromide in lethally irradiated rats. Indian. J. Exp. Biol., (9): 785 - 787.

Berroud, A.; LeRoy, A. and Voisin, P. (1996): Membrane oxidative damage induced by ionizing radiation detected by fluorescence polarization. Radiat. Environ. Biophys., 35 (4): 289 - 295.

Chihara, K.; Iwaski, J.; Minamitani, N.; Kaja, H.; Matsumoto, S. and Fujita, T. (1982): Effect of vasoactive intestinal polypeptide on growth hormone secretion in perfused acromegalic pituitary adenoma tissues. J. Clin. Endocrinol. Metab., 54 (4): 773 - 779.

Cohen, E. P. (2001): Renal failure after bone marrow transplantation. Lancet., 357: 6-7.

Cohen, E. P.; Fish, B. L., Moulder, J. E. (2002): The renin-angiotensin system in experimental radiation nephropathy. J. Lab. Clin. Med., 139: 251-257.

Cohen, E. P. and Robbins, M. E. C. (2003): Radiation nephropathy. Semin Nephrol 23: 486-499.

Dacie, J. V. and Lewis, S. M. (1975): Practical haematology $5^{\text {th }}$ edition. The English Language Book Society and Churchill Living stone.

Dong, W.; Wang, L.; Kong, T. and He, Y. (2009): Scorpion venom peptides accelerate hematopoietic recovery of myelosuppression in irradiated mice. Am J Chin Med., 37(4):701-12.

Doumas, B. T.; Watson, W. A. and Biggs, H. G. (1971): Albumin standards, serum albumin measurment, bromcresol green. Clin. Chem., 7: 87 - 96.

Doumas, B. T.; Biggs, H. G.; Arends, R. L. and Pinto, P. V. C. (1972): Determination of serum albumin. Standared methods. Clin. Chem., 7: 175 - 188. 
El-Asmar, M. F.; Ziada, N. A.; Ismail, M. and Osman, D. H. (1975): Effect of scorpion (Buthus minox, L. koch) venom on calcium, phosphorous, alkaline phosphatase and serum proteins of rat. Ain Shams Med. J., (26): 683 - 686.

El-Missiry, M. A. (1999): Bee pullens as an antioxidant for the control of radiation induced oxidative stress in male rats. J. Egypt. Ger. Soc. Zool., 29: 121 - 132.

El-Missiry, M. A.; Roushdy, H. M.; Fayed, Th. A. and Shahat, O. G. (1998): Role of bone marrow treatment for gamma radiation induced changes rats. J. Uni. Arab. Biol., 20 (A): 354 - 370.

El-Missiry, M. A.; Fayed,T. A.; El-Sawy, M.R.and El-Sayed, A. A. (2007): Ameliorative effect of melatonin against gamma-irradiation-induced oxidative stress and tissue injury. Ecotoxicol. Environ. Saf. 66(2): 278-286.

Enjalbert, R.; Arancibia, S.; Ruberg, M.; Priam, M.; Bluet-Pajot, M. T.; Rotsztein, W. H. and Kordon, C. (1980): Stimulation of in vitro prolactin release by vasoactive intestinal peptide. Neuroendocrinl., 31: 200 - 204.

Ferreira, S. H. (1965): A bradykinin-potentiating factor (BPF) present in the venom of Bothrops jararaca. Br. J. Pharmac. Chemother., 24: 163 - 169.

Frawley, L. S. and Neill, J. D. (1981): Stimulation of prolactin secretion in rhesus monkeys by vasoactive intestinal polypeptide. Neuroendocrinol., 33: 79 - 83.

Guyton, A. C. and Hall, J. E. (2000): The microcirculation and the lymphocytic system: capillary fluid exchange, interstitial fluid and lymph flow. In: Medical physiology $10^{\text {th }}$ ed. (Guyton, A. C. and Hall, J. E., eds), chapter No. 16, pp 162 $-174$.

W. B. Saunders co., NY. Karalenka, A. A.; Korolik, E. V.; Ivanova, N. V.; Zhbankow, R. G.; Yanushchwski, D. S.; Zhbankow, V. M. and Konoplya, E. F. (1993): Assessment of the albumin of animal blood plasma after single acute $\gamma$ - irradiation. Vest. Akad. Navu.,4: 51-53.

Kehrer, G.; Aminalai, A.; Gersing, E.; Lamesch, P.; Meissner, A.; Schareck, W. D.; Richter, T. and Bretschneider, H. J. (1990): Glycogen effects energy state and passive electric properties of liver during protection. Z. Gastroenterol., 28: (3): $147-156$.

Khamis, F. L. (1986): Bone marrow transplantation for treatment of some radiation induced biochemical disorders in Albino rat Egypt. J. Radiat. Sci. Aplicat., 3(2):149-185.

Marinova, T. S.; Georgieva, T. R. and Pantev, T. (1991): Protien synthesis changes in peripheral blood leukocytes following in vivo and in vitro irradiation mammalian spermatogonia. Rentgen. Radiolog., 30 (1): 63 - 66.

Meier, J. and Theakston, R. D. Q. (1986): Approximate LD $_{50}$ Determinations of snake venoms using eight to ten experimental animals. Toxicon, 24(4): 395-401.

Muriel, P. (1998): Nitric oxide protection of rat liver from lipid peroxidation, collagen accumulation, and liver damage induced by carbon tetrachloride. Biochem. Pharmacol., 56 (6): 773 - 779.

Nassar, A. Y.; Abu-Sinna, G. and Abu-Amra, S. (1989): Isolated fractions from toxins of Egyptian scorpions and cobra, activated smooth muscle contraction and glomerular filtration. Toxicon, 27: 57(abstract).

Nassar, A. Y.; Abu-Sinna, G. and Abd-El-Rahim, S. (1990): Effect of a bradykinin potentiating fraction, isolated from venom of the Egyptian scorpion, Buthus occitanus, on the ovaries and endomertrium of mice. Toxicon, 28: 525 - 534.

Nassar, A. Y.; Abu-Sinna, G.; El-Saadani, M. and Abd-El-Rahim, S. (1991): Effect of a bradykinin potentiating fraction, isolated from venom of the Egyptian scorpion, Buthus occitanus, on spermatogenesis of premature mice. (abstract). 
$10^{\text {th }}$ World congress on animal, plant and micobiol toxins. $3-8$ November. Singaphore.

Nassar, A. Y.; Abu-Sinna, G.; Soliman, F. M.; Abd-El-Rahim, S. and El-Saadani, M. (1992): Bradykinin potentiating fraction, isolated from venom of Buthus occitanus, promotes spermatogenesis in premature mice. In Recent advances in toxinology research. Gopalakri. Shnakone. ed.,Vol. 2 pp. 119- 129. Singaphore.

Nassar, A. Y. and Soliman, F. M. (1989): Fractions with bradykinin potentiating activity composed of 14-16 amino acid residues were isolated from venoms of the Egyptian scorpions and snakes. Assiut Medical J., 13 (2): 39 - 44.

Oppenheim, J. J.; Sadler, B. M.; Siraganian, R. P.; Mage, M. and Mathieson, B. (1982): Lymphokines: their role in lymphocyte responses. Properties of Interleukin-1. Fed. Proc., 41: 257- 262.

Othman, A. I. (1998): Radioprotective effect of mercaptopropinyglycine and selenium on antioxidants and enzyme heme biosynthesis in irradiated rats. J. Egypt. Ger. Soc. Zool., 27 (A): 43 - 55.

Öztürk, Y. (2001): Kinin receptors and their antagonists as novel therapeutic agents. Curr. Pharm., 7(2):135 - 161.

Peters, T. Jr. (1968): Proposals for standardization of total protein assays. Clin. Chem., 14 (12): 1147-1159.

Salman, M. M. A. (1995): Effect of a bradykinin potentiating factor isolated from scorpion venom, Buthus occitanus on burnt skin of Guinea pig in comparison with other drugs. M. Sc. Thesis, Faculty of Science, Ain Shams University.

Salman, M. M. A. (2002): Serological, hematological and biochemical studies on bradykinin Potentiating factor isolated from scorpion venom. D. Ph. Thesis, Faculty of Science, Ain Shams University.

Salman, M. M. A. (2008): Effect of a bradykinin potentiating factor isolated from scorpion venom on red blood cells indices in alloxan-induced diabetic guinea pigs. $3^{\text {rd }}$ international conference on natural toxins, Cairo-Egypt, 16-18 December 2008.

Schmaier, A. H.; Wahl, R.; Fisher, S. J. and Brenner, D. (1998): The pharmacokinetics of the kininogens. Thromb. Res., 92 (6): $293-297$.

Sharon, N. and Lis, H. (1981): Glycoproteins: research booming on long ignored ubiquitous, compounds.Chem. Eng. Nows, 59: 21-44.

Simsa, J. and Mráz, J. (1974): Changes in the contents of some rat serum proteins under pathologic conditions. 1. The effect of ionizing radiation. Radiobiol Radiother (Berl).15(4): 509-519.

Sukhanova, G. A. (1986): Modification with bradykinin of membrane-bound lipid peroxidation and $\mathrm{Ca}^{+}$-activity of thymus and liver. Vapr. Med. Khim., 32 (2): $21-25$.

Sukhanova, G. A.; Kliment'eva, T. K. and Dokshina, G. A. (1977): Bradykinin stimulation of the mitotic activity of bone marrow and thymus cells of irradiated mice. Radiobiolog., 17 (5): 739 - 742.

Tiffany, C. W. and Burch, R. M. (1989): Bradykinin stimulates tumor necrosis factor and interleukin-1 release from macrophages. FEBS Lett., 247 (2): 189 - 192.

Vijayan, E.; Samson, W. K.; Samson, W. K.; Said, S. M. and Mccann, S. M. (1979): Vasoactive intestinal peptide: Evidence for a hypothalamic site of action to release growth hormone luteinizing hormone and prolactin in conscious ovariectomized rats. Endocrinol., 104: $53-57$. 
Vlasov, P. A. and Kvacheva, I. E. (1998): Apoptosis of cells of the bone marrow hematopoietic tissue during acute radiation damage in humans and experimental animals. Izv. Akad. Nauk. Ser. Biol., (2): 220- 224.

Waldmann, T. A. (1977): Albumin catabolism In: Albumin structure, function and uses, edited by V. M. Rosenoer, M. Ortaz and M. A. Rothschild. New York; Permagon Press, pp. 255-273.

West, J. B. (1985): Blood and the plasma proteins: Function and composition of blood. In: Best and Taylor's physiological basis of medical practice. 11th edt. Williams and Wilkins, Baltimore, pp. 334- 340.

Zündorf, G.; Böckmann, S. and Paeglow, I. (1996): Bradykinin induces tyrosine phosphorylation of several proteins in Guinea pig macroph-ages. Eur. J. Haematol., 57 (Suppl.): 23.

\section{ARABIC SUMMARY}

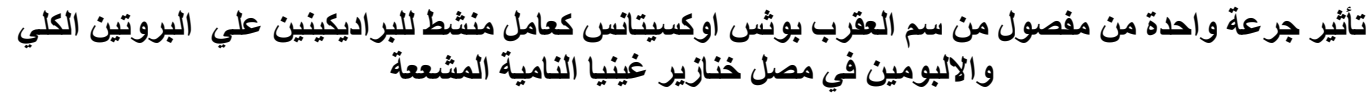

$$
\begin{aligned}
& \text { محمد محمود علي سنالمان } \\
& \text { جامعة جنوب الوادي ـ كلية العلوم بقنا ـ قسم علم الحيوان }
\end{aligned}
$$

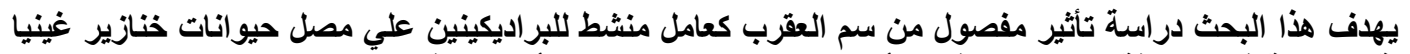

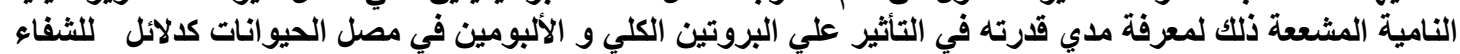

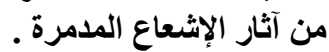

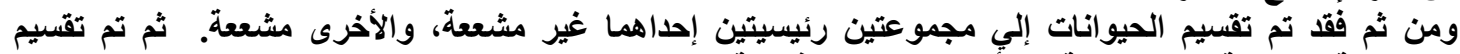

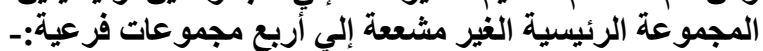

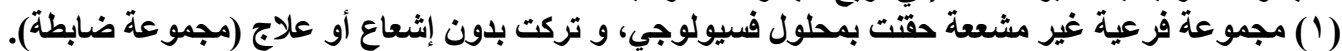

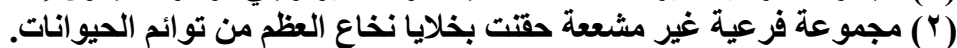

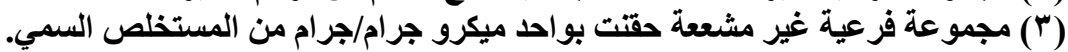

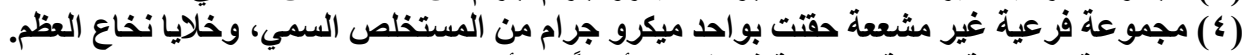

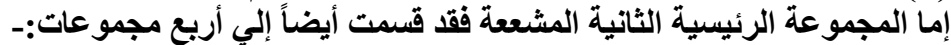

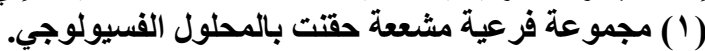

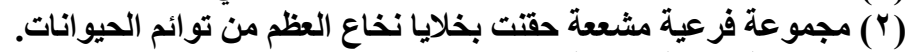

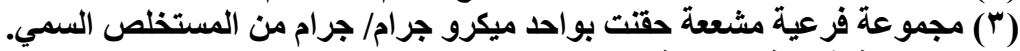

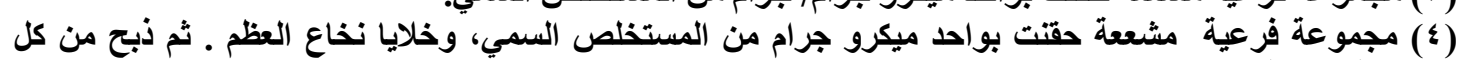

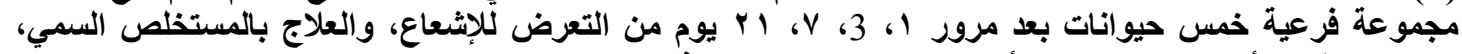

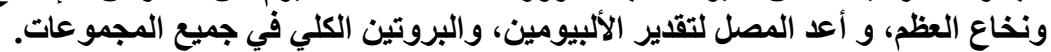

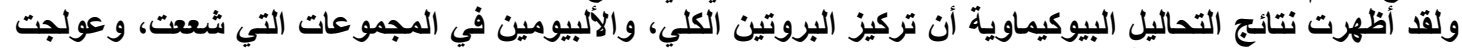

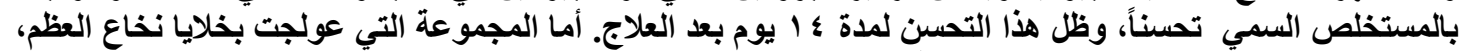

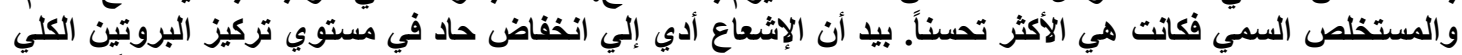

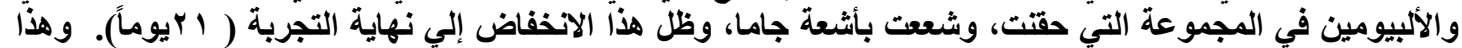

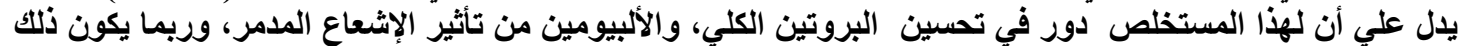

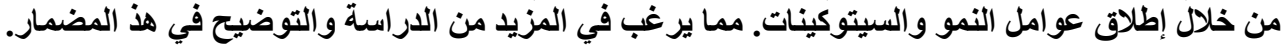

